\title{
SOLUSI MASALAH AGENSI PERUSAHAAN PUBLIK DI INDONESIA: PENDEKATAN GAME-MODELING DAN PENDEKATAN POSITIF EMPIRIS
}

\author{
Zaenal Arifin \\ Fakultas Ekonomi \\ Universitas Islam Indonesia Yogyakarta
}

\begin{abstract}
Abstrak
Struktur kepemilikan perusahaan publik di Indonesia adalah terkonsentrasi dan pemilik utamanya adalah keluarga. Di sini, masalah agensi yang muncul adalah antara pemilik non-keluarga dengan pemilik keluarga bersama manajemen. Karena pola hubungan keagenan antara keduanya bersifat berulang-berurutan maka strategi yang efektif untuk mengatasi masalah agensinya adalah strategi 'tit for tat'

Strategi 'tit for tat' ternyata dominan di Bursa Efek Jakarta pada tahun 1996 maupun pada tahun 2000. Dominasi strategi ini lebih menonjol pada perusahaan yang porsi kepemilikan keluarganya tinggi, namun menjadi tidak dominan ketika kepemilikan keluarga relatif kecil. Hasil uji empiris menunjukkan bahwa strategi 'tit for tat' hanya efektif untuk mengurangi masalah agensi ketika berbentuk reward dan tidak efektif ketika berbentuk punishment.
\end{abstract}

Kata Kunci: Strategi 'tit for tat', masalah agensi, dominasi kepemilikan keluarga

PENDAHULUAN

Dalam sistem ekonomi modern, banyak perusahaan tidak lagi dikelola oleh pemiliknya melainkan oleh manajer profesional yang digaji untuk menjalankan perusahaan sesuai kepentingan si pemilik. Kecenderungan ini mulai muncul pada awal abad 21 di Amerika Serikat, yang salah satu pemicunya adalah dikeluarkannya undang-undang anti-trust yang mendorong pemilik perusahaan perseorangan mendivestasi sebagian kepemilikannya.

Kecenderungan semakin banyaknya perusahaan yang terpisah kepemilikan dan manajemennya ini didokumentasikan oleh Berle dan Means (1932). Mereka menyatakan bahwa terpisahnya kepemilikan (ownership) dan manajemen (control) akan memunculkan masalah karena kepentingan pemilik dan manajer tidak selalu sejalan. Permasalahan yang muncul karena seorang agen (orang yang menerima tugas atau wewenang) tidak selalu bertindak sesuai dengan keinginan prinsipal (orang yang memberikan tugas atau wewenang) dikenal dengan nama masalah agensi (agency problem).

Tindakan agen yang tidak sesuai dengan keinginan prinsipal dapat muncul dalam berbagai bentuk. Dalam kasus permasalahan antara pemilik perusahaan dan manajer, masalah agensi dapat berupa peng- 
gunaan dana perusahaan untuk pembelian fasilitas manajer yang berlebihan, penahanan laba perusahaan untuk investasi yang kurang menguntungkan, dan berbagai kecurangan yang dapat mengurangi laba perusahaan seperti menjual produk perusahaan dengan harga murah ke perusahaan lain yang ternyata milik manajer. Fenomena munculnya masalah agensi inilah yang kemudian mendorong munculnya teori agensi (agency theory). Jensen (1983) mengidentifikasi ada dua pendekatan dalam pengembangan teori agensi yang dia namakan "positive theory of agency" dan "principal-agent literatures". Kedua pendekatan sama-sama menelaah kontrak diantara self-interested individuals dan sama-sama berpostulat bahwa biaya agensi (agency cost) dapat diminimumkan dengan melalui proses kontrak serta sama-sama bertujuan mendesain kontrak yang Pareto-efficient. Meskipun demikian, keduanya memiliki perbedaan dalam beberapa hal. Principal-agent literature pada umumnya berorientasi matematis atau modeling (terutama game modeling) dan non-empiris serta berkonsentrasi pada efek dari preferensi dan asymmetric information. Sementara itu positive agency literature pada umumnya berfokus pada uji empiris (seperti model ekonometri) dan non-matematis serta berkonsentrasi pada efek dari teknologi sistem kontrak dan human atau physical capital yang spesifik. Yang agak mengherankan adalah penulis/peneliti dari kedua pendekatan sepertinya bekerja terpisah. Sangat jarang ditemukan suatu artikel dari salah satu pendekatan yang mengacu hasil analisis atau temuan dari pendekatan yang lainnya. Dalam penelitian ini, penulis berkeinginan menganalisis masalah agensi di Indonesia dengan memakai baik pendekatan principal-agent maupun pendekatan positive- agency.

Selama ini pengembangan teori agensi dan uji empirisnya sebagian besar mendasarkan analisisnya pada fenomena perusahaanperusahaan di Amerika Serikat yang kepemilikannya cenderung menyebar seperti dikemukakan Berle dan Means (1932). Masalah muncul karena di dunia saat ini, seperti dikemukakan oleh Coffee (2001), terdapat dua sistem corporate governance yang keduanya sama-sama bertahan hidup yaitu sistem kepemilikan yang menyebar dan sistem kepemilikan yang terkonsentrasi. Di era pasar global dan tingkat kompetisi yang semakin ketat dan jika kita mengacu pada teori Darwin tentang keberlangsungan hidup suatu entitas, maka mestinya hanya perusahaan yang paling efisien saja yang akan dominan. Kenyataannya, sistem kepemilikan-menyebar banyak ditemui di Amerika Serikat dan Inggris sedangkan di negara-negara maju lainnya serta di negara-negara sedang berkembang kebanyakan sistem kepemilikannya adalah terkonsentrasi.

La Porta et al (1999) melakukan survai terhadap struktur kepemilikan perusahaan-perusahaan besar yang go public di 27 negara kaya. Dengan menggunakan definisi kontrol 20\% (artinya perusahaan memiliki 
"pemegang saham pengontrol" jika ada satu atau lebih pemegang saham yang memiliki porsi kepemilikan $20 \%$ atau lebih, jika tidak ada berarti kepemilikannya menyebar) mereka menemukan bahwa 36\% perusahaan kepemilikannya menyebar, 30\% dikontrol oleh keluarga, dan 18\% dikontrol oleh negara. Ketika definisi kontrolnya diturunkan menjadi $10 \%$ atau lebih maka yang kepemilikannya menyebar turun menjadi $24 \%$, yang dikontrol keluarga meningkat menjadi 35\% dan yang dikontrol negara meningkat menjadi 20\%. Dari temuan tersebut nampak bahwa pada sebagian besar perusahaan besar di negara-negara maju kepemilikannya terkonsentrasi dan yang menjadi pemegang kendali utamanya adalah keluarga. Dominasi sistem corporate governance dengan kepemilikan terkonsentrasi semakin jelas pada perusahaan-perusahaan dengan ukuran sedang. Pada perusahaan-perusahaan ini perusahaan yang kepemilikannya menyebar hanya $24 \%$ untuk definisi kontrol $20 \%$.

Bagaimana struktur kepemilikan perusahaan di Indonesia? Dalam surveynya terhadap 9 negara di Asia Timur, Claessens, Djankov, dan Lang (2000) menemukan bahwa pada tahun 1996 perusahaan Indonesia yang kepemilikannya menyebar, jika menggunakan difinisi kontrol $10 \%$, hanya $0,6 \%$, sama dengan keadaan di Hongkong. Jika menggunakan definisi kontrol $20 \%$, porsi yang kepemilikannya menyebar meningkat menjadi $5.1 \%$. Angka ini adalah angka yang paling rendah di antara sembilan negara yang disurvei. Claessens, et al juga menemukan bahwa pengontrol utama dari kebanyakan perusahaan go public adalah keluarga. Di Indonesia, porsi kontrol keluarga adalah yang paling tinggi yaitu $71.5 \%$ (untuk $20 \%$ cutoff), dan yang dikontrol negara adalah $8.2 \%$, tertinggi ketiga setelah Singapura dan Malaysia. Sisanya dikontrol oleh perusahaan publik nonfinansial $13,2 \%$ dan perusahaan publik finansial $2 \%$.

Dengan pola kepemilikan yang terkonsentrasi dan pemilik utama (ultimate control) yang dominan adalah keluarga, pertanyaan pokok yang muncul adalah mekanisme apa yang dapat digunakan dengan efektif untuk mengurangi masalah agensi pada perusahaa-perusahaan di Indonesia. Jawaban atas pertanyaan ini sangat relevan bagi upaya pembentukan good corporate governance di Indonesia sekaligus memberi sumbangan pada pengembangan teori struktur kepemilikan dan teori agensi dengan kondisi yang spesifik seperti di Indonesia.

\section{POKOK PERMASALAHAN}

Pokok permasalahan dalam penelitian ini adalah mekanisme kontrol apa yang efektif untuk mengurangi masalah agensi (agency problem) dalam kasus dimana sistem kepemilikan perusahaan-perusahaan sebagian besar terkonsentrasi dengan pemilik utama didominasi keluarga. Karena 
penelitian ini menganalisis masalah agensi dengan dua pendekatan sekaligus maka permasalahan yang dimunculkan juga mengacu pada dua pendekatan tersebut.

Dari pendekatan principal-agent permasalahan yang diajukan adalah: 'Bagaimana model kontrak yang Pareto-efficient untuk mengatasi masalah agensi pada kasus kepemilikan perusahaan di Indonesia?' Dari pendekatan positive-agency, permasalahan yang diajukan adalah: 'Apakah model tersebut secara empiris telah diterapkan di pasar modal Indonesia?' dan 'Apakah model kontrak tersebut secara empiris efektif untuk mengurangi masalah agensi di pasar modal Indonesia?'

\section{GAME-MODELLING MASALAH AGENSI PADA PERUSAHAAN PUBLIK}

Data awal yang diperoleh dalam rangka penelitian ini menunjukkan bahwa struktur kepemilikan perusahaan publik di Indonesia pada tahun 1996 dan tahun 2000 adalah terkonsentrasi dengan pemilik utama keluarga. Temuan ini sama dengan yang ditemukan dalam survey Claessens (2000) dengan data tahun 1996. Pada struktur kepemilikan yang terkonsentrasi dengan pemilik utama keluarga, permasalahan tidak lagi antara manajer dan pemilik karena pemilik mayoritas (keluarga) sepenuhnya dapat mengontrol manajemen. Permasalahan agensi yang muncul adalah antara manajer/pemilik mayoritas dengan pemegang saham non-mayoritas.

Fakta kepemilikan ini jika dibuat model permainannya akan berupa permainan dengan pemegang saham non-keluarga sebagai prinsipal dan pemegang saham keluarga bersama-sama dengan manajer bertindak sebagai agen. Pada perusahaan publik ini bentuk permainannya adalah permainan yang berulang-ulang dan berurutan (repeatedsequential-game) dimana agen melakukan langkah pertama dan direspon oleh prinsipal. Permainan ini memiliki sifat turnamen (tournament) karena prinsipal memiliki fleksibilitas untuk mengalihkan dananya ke perusahaan lain yang mereka anggap memiliki prospek yang lebih baik.

Pada awal permainan, pemegang saham non-keluarga (prinsipal) tidak mengetahui apakah kegiatan manajer/pemegang saham keluarga (agen) adalah baik atau buruk (kegitan agen unobservable) namun prinsipal mengetahui hasil dari kegiatan tersebut, dan hasil tersebut akan mempengaruhi kekayaan dia. Agen juga sebetulnya tidak mengetahui dengan pasti hasil akhir dari turnamen, namun dia memiliki pilihan apakah akan berbuat baik atau buruk. Pilihan kegiatan baik atau buruk dari agen akan mempengaruhi hasil (kinerja). Kinerja perusahaan pada gilirannya tidak hanya mempengaruhi kekayaan prinsipal tetapi juga mempengaruhi kekayaan agen karena agen juga memiliki saham perusahaan. 
Permainan diawali ( $\left.\mathrm{t}_{0}\right)$ ketika perusahaan keluarga melakukan initial public offering dan pemegang saham non-keluarga mulai berinvestasi ke perusahaan tersebut. Ketika akan berinvestasi pemegang saham nonkeluarga tidak mengetahui apakah manajer/pemegang saham keluarga memiliki sifat yang baik (good agent) atau buruk (bad agent) tetapi yang jelas di pasar terdapat agen yang baik dan juga agen yang buruk. Pada awal investasi, investor hanya memprediksi bahwa saham yang mereka beli dikeluarkan oleh perusahaan yang dikelola dengan baik oleh manajer (agen)-nya.

- Probabilitas perusahaan dikelola oleh agen yang baik $=\theta$

- Probabilitas perusahaan dikelola oleh agen yang buruk = (1- $\theta)$

Definisi agen yang baik adalah agen yang keputusankeputusannya lebih condong kepada kepentingan pemegang saham (karena sebenarnya mereka juga pemegang saham) dan agen yang buruk adalah agen yang keputusan-keputusannya lebih condong kepada kepentingan mereka sebagai manajer.

Setelah berjalan satu periode $\left(\mathrm{t}_{1}\right)$, pemegang saham non-keluarga akan menilai kinerja dari agen. Untuk menampung unsur turnamen, kinerja diukur berdasarkan return yang diperoleh suatu perusahaan dibandingkan dengan return rata-rata pasar. Kinerja perusahaan dinilai baik $(G)$ jika returnnya di atas return rata-rata pasar dan dinilai buruk (B) jika kinerja lebih rendah dibandingkan rata-rata pasar.

Perusahaan yang dikelola oleh agen-baik maupun agen-buruk pada saat $\mathrm{t}_{1}$ dapat memperoleh nilai-baik atau nilai-buruk, walaupun perusahaan yang dikelola oleh agen-baik memiliki probabilitas berkinerja-baik lebih besar dan perusahaan yang dikelola oleh agen-buruk memiliki probabilitas berkinerja-buruk lebih besar.

- $P($ Perusahaan berkinerja $G)=\lambda$

- $P($ Perusahaan berkinerja $B)=(1-\lambda)$

- $P($ Perusahaan dikelola agen-baik dan berkinerja $G)=\theta \lambda$

- $P($ Perusahaan dikelola agen-buruk dan berkinerja $G)=(1-\theta) \lambda$ $\theta \lambda>(1-\theta) \lambda$

- $P($ Perusahaan dikelola agen-buruk dan berkinerja $B)=(1-\theta)(1-\lambda)$

- $P($ Perusahaan dikelola agen-baik dan berkinerja $B)=\theta(1-\lambda)$ $(1-\theta)(1-\lambda)>\theta(1-\lambda)$

Dengan diketahuinya kinerja perusahaan pada periode $t_{1}$, investor akan melakukan revisi atas penilaian mereka terhadap perusahaan. Misal keyakinan investor pada to (prior probability) bahwa perusahaan adalah baik dinotasikan $\mathbf{r}_{0}$. Pada $t_{1}$ mereka telah mendapat bukti bahwa perusahaan ternyata memang baik atau ternyata buruk. Dengan memakai Bayes' 
rule maka posterior probability bahwa perusahaan adalah baik dengan telah diamatinya $\mathrm{G}$ atau $\mathrm{B}$ pada $\mathrm{t}_{1}$ adalah:

$r_{G}\left(r_{0}\right)=r_{0} \theta \lambda /\left[r_{0}(\theta \lambda)+\left(1-r_{0}\right)(1-\theta) \lambda\right]$

$r_{B}\left(r_{0}\right)=r_{0} \theta(1-\lambda) /\left\{r_{0} \theta(1-\lambda)+\left(1-r_{0}\right)[(1-\theta)(1-\lambda)]\right.$

$r_{G}\left(r_{0}\right)>r_{B}\left(r_{0}\right)$

Misalkan keyakinan investor pada to (prior probability) bahwa perusahaan adalah buruk dinotasikan $\left(1-r_{0}\right)$. Pada $t_{1}$ mereka telah mendapat bukti bahwa perusahaan ternyata memang baik atau ternyata buruk. Dengan memakai Bayes' rule maka posterior probability bahwa perusahaan adalah buruk dengan telah diamatinya $\mathrm{G}$ atau $\mathrm{B}$ pada $\mathrm{t}_{1}$ adalah:

$r_{G}\left(1-r_{0}\right)=\left(1-r_{0}\right)(1-\theta) \lambda /\left[r_{0}(\theta \lambda)+\left(1-r_{0}\right)(1-\theta) \lambda\right]$

$r_{B}\left(1-r_{0}\right)=\left(1-r_{0}\right)(1-\theta)(1-\lambda) /\left\{r_{0} \theta(1-\lambda)+\left(1-r_{0}\right)[(1-\theta)(1-\lambda)]\right.$

$r_{B}\left(1-r_{0}\right)>r_{G}\left(1-r_{0}\right)$

Secara skematis pola hubungan antara agen dan prinsipal dapat diilustrasikan dalam Gambar 1 di bawah ini.

Gambar 1: Skema Game-Modelling antara Pemegang Saham Non-Keluarga dan Agen

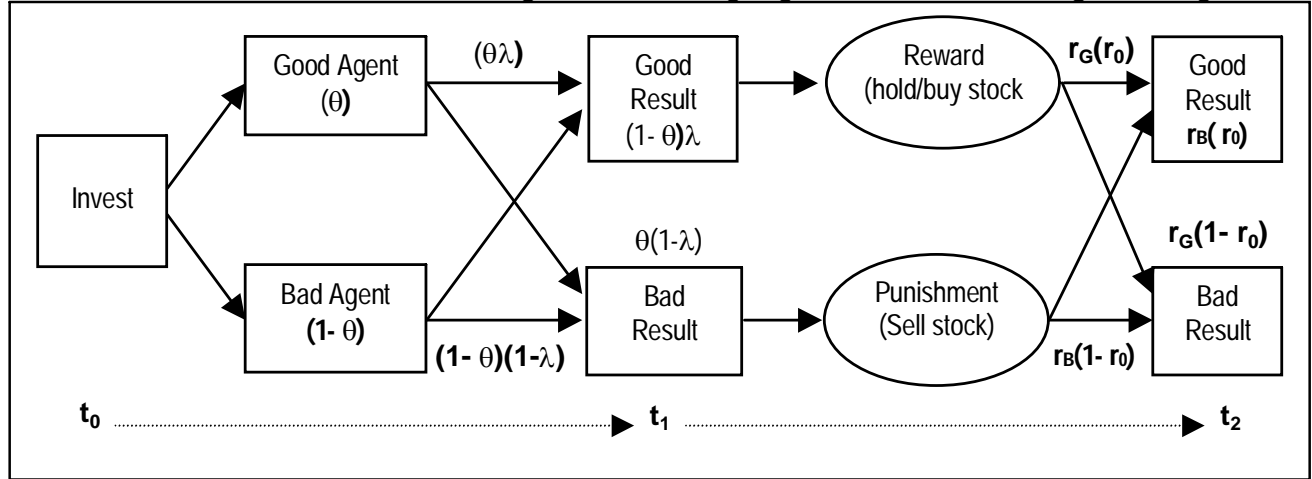

Revisi probabilitas (keyakinan) seperti yang digambarkan tersebut akan terus berulang setiap periode setelah prinsipal mengetahui kinerja perusahaan pada periode yang bersangkutan. Namun yang pasti adalah probabilitas suatu perusahaan berkinerja-baik akan lebih besar pada perusahaan yang sebelumnya sudah berkinerja-baik. Sebaliknya probabilitas perusahaan berkinerja-buruk akan lebih besar pada perusahaan yang sebelumnya sudah berkinerja-buruk.

\section{HIPOTESIS UJI EMPIRIS DARI GAME MODELLING}

Reaksi keyakinan atas kinerja baik perusahaan dinyatakan dalam tindakan apakah prinsipal tetap memegang saham, membeli lagi saham, atau menjual saham perusahaan tersebut. Perusahaan yang diyakini akan berkinerja baik sahamnya akan ditahan atau kalau perlu melakukan pem- 
belian lagi sedangkan perusahaan yang diyakini akan berkinerja buruk sahamnya akan dijual.

Menurut Varian (1999), solusi yang cukup berhasil dalam repeated-sequential games adalah strategi "tit for tat". Jika diterapkan dalam konteks masalah agensi antara pemegang saham non-keluarga, yang bertindak sebagai prinsipal, dengan manajer/pemegang saham-keluarga, yang bertindak sebagai agen, maka prinsipal akan "menghukum" agen jika kinerja perusahaan buruk dan akan memberi "penghargaan" jika kinerjanya baik.

Dalam game yang diuraikan di atas, penghargaan prinsipal dinyatakan dengan membeli (buy) dan atau menahan (hold) saham perusahaan dan hukuman dinyatakan dengan menjual (sell) saham perusahaan. Jika prinsipal memakai strategi "tit for tat" maka mestinya kinerja perusahaan pada suatu periode akan berkaitan positif dengan kinerja perusahaan pada periode sebelumnya. Perusahaan yang berkinerja bagus pada suatu periode akan diberi penghargaan oleh prinsipal dengan membeli dan menahan sahamnya sehingga diperkirakan kinerjanya pada periode berikutnya akan tetap bagus. Sedangkan perusahaan yang kinerjanya buruk akan dihukum prinsipal dengan menjual sahamnya sehingga diperkirakan kinerja perusahaan tersebut pada periode berikutnya juga buruk. Dengan demikian, jika pemegang saham non-keluarga memang memakai strategi 'tit-for-tat' sebagai model yang efektif untuk mengurangi masalah agensi maka kinerja perusahaan pada suatu periode berkorelasi positif dengan kinerja perusahaan pada periode sebelumnya. Karena secara modelling strategi 'tit for tat' cukup efektif untuk mengurangi masalah agensi diperkirakan strategi ini banyak dipakai oleh investor (prinsipal) untuk mengontrol agen (manajemen dan pemilik keluarga) di pasar modal Indonesia dan perusahaan yang investornya memakai strategi 'tit for tat' kinerjanya diperkirakan akan lebih baik dibandingkan dengan perusahaan yang investornya tidak memakai strategi 'tit for tat'. Hipotesis yang akan diuji adalah:

H1: Strategi 'tit for tat' dipakai oleh investor non keluarga untuk mengontrol manajer dan pemilik keluarga pada perusahaan di pasar modal Indonesia.

H2: Perusahaan yang investornya memakai strategi 'tit for tat' kinerjanya lebih baik dibandingkan dengan perusahaan yang investornya tidak memakai strategi 'tit for tat'

\section{METODE PENELITIAN}

\section{Perusahaan yang Dianalisis}

Perusahaan yang dianalisis dalam penelitian ini adalah perusahaan publik yang terdaftar di Bursa Efek Jakarta (BEJ) pada awal tahun 1996 dan masih tetap terdaftar hingga akhir tahun 2000. Sedangkan anali- 
sis hanya dilakukan pada tahun 1996 dan tahun 2000 saja. Tahun 1996 dianalisis untuk memberi gambaran kondisi masalah agensi sebelum terjadi krisis ekonomi sedangkan tahun 2000 untuk memberi gambaran kondisi setelah krisis ekonomi. Pada awal tahun 1996 terdapat 238 perusahaan yang terdaftar di BEJ dan yang masih tetap bertahan hingga akhir tahun 2000 ada 213 perusahaan. Karena ada data yang tidak lengkap maka perusahaan yang dianalisis pada tahun 1996 tinggal 196 perusahaan dan pada tahun 2000 ada 212 perusahaan.

\section{Langkah Analisis dan Uji Validitasnya}

Model yang digunakan untuk menguji hipotesis 1 adalah model autoregressive moving average (ARMA) dan akan disesuaikan menjadi model autoregressive integrated moving average (ARIMA) jika series bersifat tidak stasioner, serta menjadi model autoregressive conditionally heteroskedastic (ARCH) atau generalized autoregressive conditionally heteroskedastic (GARCH) jika ditemukan adanya masalah heteroskedastisitas dalam series. Jika koefisien autoregressive (AR) positif signifikan maka strategi 'tit for tat' dilakukan oleh investor. Dimasukkankan moving average, ARCH, dan GARCH term dalam model uji berlaku tidaknya strategi 'tit for tat' karena karakteristik data return saham pada umumnya memang memiliki pola moving average dan heteroskedastik.

Untuk uji stasioneritas digunakan Augmented Dickey-Fuller (ADF) test dan untuk uji heteroskedastisitas digunakan Autoregressive $\mathrm{He}$ teroskedastity Lagrange Multiplier (ARCH LM) test. Uji autokorelasi juga dilakukan untuk menentukan ordo dari model ARMA dan uji yang dipakai adalah Ljung-Box Q-Statistic.

Model uji hipotesis 2 adalah cross-section ordinary least square. Uji autokorelasi menggunakan Ljung-Box Q-Statistic Test seperti dalam uji hipotesis 1 sedangkan uji heteroskedastisitas menggunakan White Heteroskedasticity Test yang memang cocok untuk model OLS. Variabel independen utama dalam uji hipotesis 2 adalah variabel dummy dipakainya strategi 'tit for tat' (DARPOSITIF) yang memiliki nilai 1 jika koefisien AR term signifikan positif dan memiliki nilai 0 untuk lainnya.

\section{HASIL UJI EMPIRIS PEMAKAIAN STRATEGI 'TIT FOR TAT' DI PASAR MODAL INDONESIA}

Uji dipakainya strategi 'tit for tat' di pasar modal Indonesia memakai abnormal return mingguan dari tiap-tiap saham yang dianalisis sebagai proxy dari kinerja. Abnormal return mingguan adalah return saham selama satu minggu dikurangi dengan return pasar dalam minggu yang sama. Dengan demikian proxy ini dapat memberi gambaran adanya turnamen, dan pemenangnya adalah saham yang paling besar abnormal return- 
nya. Rekapitulasi hasil analisis time series perusahaan per perusahaan ditampilkan dalam Tabel 1 berikut ini.

Tabel 1 : Rekapitulasi Hasil Uji H1 untuk Seluruh Perusahaan

Model Umum Uji H1:

$$
\begin{aligned}
\text { ARet }_{\mathrm{t}}= & \alpha_{0}+\alpha_{1} \text { ARet }_{\mathrm{t}-1}+\alpha_{2} \text { ARet }_{\mathrm{t}-2}+\ldots+\alpha_{\mathrm{p}} \text { ARet }_{\mathrm{t}-\mathrm{p}}+\varepsilon_{\mathrm{t}}+\beta_{0} \varepsilon_{\mathrm{t}-1}+\beta_{1} \varepsilon_{\mathrm{t}-2}+ \\
& \ldots+\beta_{\mathrm{q}} \varepsilon_{\mathrm{t}-\mathrm{q}} \\
\sigma_{\mathrm{t}}^{2} & =\alpha_{0}+\alpha_{1} \sigma_{\mathrm{t}-1}^{2}+\alpha_{2} \sigma_{\mathrm{t}-2}^{2}+\ldots+\alpha_{\mathrm{p}} \sigma_{\mathrm{t}-\mathrm{p}}^{2}+\beta_{1} \varepsilon_{\mathrm{t}-1}^{2}+\beta_{2} \varepsilon_{\mathrm{t}-2}^{2}+ \\
& \ldots+\beta_{\mathrm{q}} \varepsilon_{\mathrm{t}-\mathrm{q}}^{2}
\end{aligned}
$$

Dimana ARet adalah abnormal return mingguan, ARett-1 adalah lag 1 dari abnormal return (sama dengan $\mathrm{AR}(1)$ ), $\varepsilon_{\mathrm{t}}$ adalah forecasting error, $\varepsilon_{\mathrm{t}-1}$ adalah lag dari forecasting error (sama dengan MA(1)), $\sigma^{2}$ adalah variance

\begin{tabular}{|c|c|c|c|c|}
\hline Keterangan & AR (1) & MA (1) & ARCH (1) & GARCH (1) \\
\hline $\begin{array}{l}\text { Tahun 1996: } \\
(\mathrm{n}=196)\end{array}$ & & & & \\
\hline (+) Signifikan/tidak signifikan & $70 / 36$ & 34 / 34 & $7 / 13$ & $6 / 9$ \\
\hline $\begin{array}{l}\text { (-) Signifikan/tidak signifikan } \\
\text { Nilai rata2: }\end{array}$ & $35 / 55$ & $90 / 38$ & $1 / 3$ & $5 / 4$ \\
\hline Koefisien & 0.097573 & -0.26982 & 0.023353 & 0.024734 \\
\hline $\begin{array}{l}\text { Tahun 2000: } \\
(\mathrm{n}=212)\end{array}$ & & & & \\
\hline $\begin{array}{l}\text { (+) Signifikan/tidak signifikan } \\
\text { (-) Signifikan/tidak signifikan }\end{array}$ & $\begin{array}{l}53 / 55 \\
47 / 57\end{array}$ & $\begin{array}{l}50 / 39 \\
74 / 49\end{array}$ & $\begin{array}{l}7 / 16 \\
4 / 3\end{array}$ & $\begin{array}{l}13 / 10 \\
2 / 5\end{array}$ \\
\hline $\begin{array}{l}\text { Nilai rata2 } \\
\text { Koefisien }\end{array}$ & -0.04209 & -0.15057 & 0.022722 & 0.05825 \\
\hline
\end{tabular}
dari forcasting error, $\sigma_{\mathrm{t}-1}^{2}$ adalah lag dari variance forecasting error (sama dengan ARCH (1) term), dan $\varepsilon_{\text {t-1 }}^{2}$ adalah lag dari nilai forecasting error kuadrat (sama dengan GARCH (1) term).

Dari Tabel 1 terlihat bahwa nilai rata-rata koefisien $A R(1)$ atau ARett-1 adalah positif untuk tahun 1996 dan negatif untuk tahun 2000. Kalau nilai-nilai ekstrem dihilangkan dengan cara hanya memperhatikan arah koefisiennya saja maka pada tahun 2000 juga menghasilkan nilai yang positif. Hasil yang konsisten juga diperoleh jika yang dihitung hanya koefisien AR(1) yang signifikan saja, baik pada tahun 1996 maupun pada tahun 2000 lebih banyak perusahaan yang koefisiennya positif dibandingkan dengan yang negatif. Mencermati koefisien yang signifikan akan memberi gambaran yang lebih akurat tentang pola hubungan antara kinerja sekarang dengan kinerja sebelumnya. Temuan bahwa koefisien AR(1) 
yang signifikan positif lebih banyak dibandingkan dengan yang signifikan negatif menunjukkan bahwa strategi 'tit for tat' lebih dominan dipakai oleh investor di Bursa Efek Jakarta dibandingkan dengan strategi teknikal. Strategi 'tit for tat' mengandalkan kinerja yang lalu untuk melakukan tindakan pada periode sekarang dengan cara jika kinerja suatu saham sebelumnya baik maka investor akan membeli atau menahan saham dan menjualnya jika kinerjanya buruk. Strategi 'teknikal' juga mengandalkan kinerja periode yang lalu namun dengan cara membeli saham yang undervalued dan menjual saham yang overvalued. Saham yang pada periode lalu menurun harga (kinerja) nya akan meningkat harganya pada periode sekarang karena saham tersebut dianggap undervalued dan sebaliknya, sehingga akan membentuk hubungan yang negatif antara kinerja saham suatu periode dengan periode berikutnya.

Analisis khusus terhadap kelompok perusahaan yang dikontrol keluarga menunjukkan bahwa dominasi strategi 'tit for tat' semakin menonjol. Sedangkan pada perusahaan-perusahaan yang kepemilikan keluarganya rendah, strategi 'tit for tat' tidak lagi dominan. Nampaknya pada saat kepemilikan keluarga masih relatif besar, mereka akan bekerjasama untuk menjaga nilai perusahaan.

Dari Tabel 1 juga nampak bahwa koefisien moving average (MA) banyak yang signifikan negatif. Greene (1997) menamakan komponen moving average sebagai innovation. Ini karena moving average term hanya mencerminkan informasi baru sampai dengan lag moving average yang dimaksud. Dengan demikian, banyaknya koefisien MA(1) yang signifikan negatif berarti telah terjadi overshooting terhadap harga-harga saham dalam menanggapi informasi baru.

Dalam penelitian ini ditemukan bahwa koefisien ARCH dan GARCH hanya sedikit yang signifikan. Ini menunjukkan bahwa pola heteroskedastik tidak banyak ditemui dalam return saham di pasar modal Indonesia. Pola heteroskedastik ini dapat muncul pada perusahaan-perusahaan yang kerap mendapat rumor. Itulah mengapa dari sedikit perusahaan yang koefisien ARCH atau GARCH-nya signifikan adalah perusahaan yang sahamnya relatif likuid seperti Astra Internasional, Indosat, dan Telkom.

\section{EFEKTIFITAS STRATEGI 'TIT FOR TAT' DI PASAR MODAL INDONESIA}

Dalam model uji $\mathrm{H} 2$ dimasukkan dua variabel kontrol yaitu ukuran perusahaan (mengacu Volpin, 2002 dan Mitton, 2002) dan book to market value of equity (mengacu Fama dan French, 1992). Hasil uji empiris menunjukkan bahwa hanya strategi 'tit for tat' yang berbentuk reward yang terbukti efektif untuk mengurangi masalah agensi. Strategi 'tit for tat' yang berbentuk punishment belum efektif untuk mengurangi masalah agensi. 
Salah satu penyebabnya karena investor kurang konsisten dalam menerapkan strategi 'tit for tat'. Investor yang memakai strategi 'tit for tat' pada tahun 1996 pada suatu perusahaan tidak selalu memakainya kembali pada perusahaan tersebut pada tahun 2000. Panel A Tabel 2 menampilkan output hasil uji efektifitas strategi 'tit for tat' dalam dua bentuk sedangkan Panel B menampilkan hasil uji untuk strategi 'tit for tat' dalam bentuk reward.

Tabel 2 : Hasil Uji Efektifitas Strategi 'Tit for Tat' di Bursa Efek Jakarta CAR $_{i}=\alpha+\beta$ DARPOSITIF $_{i}+\gamma_{1}$ LnSize $_{i}+\gamma_{2}$ BME $_{i}+\varepsilon_{1}$ CAR $_{i}=\alpha+\beta$ DARPOSPOS $_{i}+\gamma_{1}$ LnSize $_{i}+\gamma_{2}$ BME $_{i}+\varepsilon_{1}$

Dimana, CAR adalah cumulative abnormal return perusahaan $\mathrm{i}$ selama satu tahun (1996 dan 2000) merupakan penjumlahan abnormal return mingguan selama setahun, DARPOSITIF = Variabel dummy dengan nilai 1 jika koefisien ARett-1 di persamaan 9 signifikan positif dan sama dengan 0 jika lainnya, DARPOSPOS = Variabel dummy dengan nilai 1 jika koefisien ARett-1 di persamaan 9 signifikan positif serta abnormal returnya positif dan sama dengan 0 jika lainnya, LnSizei = Log rata-rata nilai pasar saham perusahaan i selama tahun 1996 dan 2001, $\mathrm{BME}_{\mathrm{i}}=$ book to market value of equity perusahaan i tahun 1996 dan 2001, dan $\varepsilon_{\mathrm{i}}=$ error term. LnSize dan BME adalah variabel kontrol

A. Strategi 'tit for tat' Lengkap

\begin{tabular}{|c|r|r|r|r|}
\hline Variable & Coefficient & Std. Error & t-Statistic & Prob. \\
\hline C & -1.981941 & 1.033095 & -1.918449 & 0.0557 \\
\hline DARPOSITIF & -0.027150 & 0.089759 & -0.302481 & 0.7624 \\
\hline LSIZE & 0.366616 & 0.162958 & 2.249761 & 0.0250 \\
\hline LSIZE^2 & -0.017739 & 0.006351 & -2.793001 & 0.0055 \\
\hline BME & 0.006764 & 0.004481 & 1.509616 & 0.1319 \\
\hline DYEAR & 0.093306 & 0.070726 & 1.319255 & 0.1878 \\
\hline DYEAR*DARPOSITIF & -0.149130 & 0.133808 & -1.114505 & 0.2657 \\
\hline
\end{tabular}

B. Strategi 'tit for tat' Bentuk Reward

\begin{tabular}{|c|r|r|r|r|}
\hline Variable & Coefficient & Std. Error & t-Statistic & Prob. \\
\hline C & -1.917930 & 1.013076 & -1.893175 & 0.0590 \\
\hline DARPOSPOS & 0.482588 & 0.140445 & 3.436145 & 0.0007 \\
\hline LSIZE & 0.345142 & 0.160107 & 2.155692 & 0.0317 \\
\hline LSIZE^2 & -0.016767 & 0.006244 & -2.685264 & 0.0075 \\
\hline BME & 0.003221 & 0.004476 & 0.719611 & 0.4722 \\
\hline DYEAR & 0.072432 & 0.061513 & 1.177511 & 0.2397 \\
\hline DYEAR`DARPOSPOS & -0.045799 & 0.212490 & -0.215533 & 0.8295 \\
\hline
\end{tabular}




\section{KESIMPULAN}

Dari pendekatan game-modeling, masalah agensi antara pemegang saham non-keluarga (prinsipal) dan pemegang saham keluarga/manajemen (agen) dapat diatasi dengan strategi 'tit-for-tat'. Strategi 'titfor-tat' efektif mengurangi masalah agensi karena bentuk permainan antara prinsipal dan agen bersifat berulang-berurutan dan prinsipal mempunyai banyak pilihan untuk memindahkan dananya ke agen lain.

Uji empiris menunjukkan bahwa strategi 'tit-for-tat' lebih dominan dibandingkan strategi teknikal. Dominasi strategi 'tit for tat' lebih menonjol pada tahun 1996 untuk kelompok perusahaan yang didominasi oleh keluarga. Strategi 'tit for tat' tidak lagi dominan pada kelompok perusahaan yang kepemilikan keluarganya 5-10\%.

Uji empiris strategi 'tit for tat' di pasar modal Indonesia menunjukkan bahwa strategi tersebut hanya efektif jika polanya berupa reward dan tidak efektif jika polanya punishment. Pola reward memang akan dengan cepat tercermin dalam peningkatan kinerja, sedangkan pola punishment membutuhkan waktu untuk membuktikan keefektifitasannya. Disamping itu, dibutuhkan konsistensi penerapan strategi tersebut untuk menjaga efektifitas punishment. Sayangnya konsistensi pemakaian strategi 'tit for tat' tidak terjadi di pasar modal Indonesia. Penelitian berikutnya dapat menguji validitas efektif tidaknya strategi 'tit for tat' dengan proxy kinerja dan rentang analisis yang lain.

\section{REFERENSI}

Barle, A. dan G. Means, (1932), The Modern Corporation and private Property, dalam La Porta, et al (1999), Corporate Ownership Around the World, Journal of Finance, Vol.LIV, No. 2, April

Claessens S, S. Djankov, dan L. H. P. Lang (2000), The Separation of Ownership and Control in East Asian Corporation, Journal of Financial Economics, Vol. 58 Iss. 1, 2, Oct/Nov. pp 81- 112

Coffee Jr, C. John (2001), The Rise of Disperse Ownership: The Roles of Law and the State in Separation of Ownership and Control, The Yale Law Journal, New Haven, October.

Enders, Walter, (1995), Applied Econometric Time Series, John Wiley \& Sons, Inc USA

EViews 3 User's Guide: Quantitative Micro Software

Fama, E. H., dan K. R. French (1992), the Cross-Section of Expected Stock Return, the Journal of Finance, Vol. XLVII, No. 2, June, pp 427-465 
Greene, H. William, (1997), Econometric Analysis, Third Edition, PrenticeHall Internatioanl, Inc.

Jensen, C. Michael, (1983), Organization Theory and Methodology, Accounting Review, 58, pp319-339

La Porta, R, F. Lopez-de-Silanes, dan A. Shleifer (1999), Corporate Ownership Around the World, Journal of Finance, Vol.LIV, No. 2, April, pp 471- 517

Mitton, Todd, (2002), A Cross-Firm Analysis of the Impact of Corporate Governance on the East Asian Financial Crisis, Journal of Financial Economics, Vol 64, No. 2

Varian, R. Hal, (1999), Intermediate Microeconomics: A Modern Approach, fifth edition, W.W. Norton \& Company, New York

Volpin, F Paolo (2002), Governance with Poor Investor Protection: Evidence from Top Executive Turnover in Italy, Journal of Financial Economics, Vol 64, No.1 